\title{
Profiling 14001 and Green Key Certified Hotels in Greece: A Managerial Perspective
}

\author{
Eleni Sardianou ${ }^{1}$, Vaitsa Gkaragkani ${ }^{1}$ and Ioannis Kostakis ${ }^{1}$ \\ ${ }^{1}$ Harokopio University, School of Environment, Geography and Applied Economics, Department of Home \\ Economics and Ecology, Graduate Program of Sustainable Development
}

\begin{abstract}
The present paper attempts to profile managers' perspective of eco-labeled hotels in Greece. The aim of this study is to examine the reasons behind the decisions to be certified with EMSs, such as Green Key and ISO 14001, employing data from hotel managers in Greece. Empirical results suggest that managers' perspective is differentiated with regards to businesses characteristics. Several administrative parameters are also important to the adoption of environmental practices. Organizational and human related factors are also important for being certified with an environmental protocol. The adoption of EMSSs is a key factor to promote sustainable tourism entrepreneurship.
\end{abstract}

Keywords: Environmental management, Eco-labels, Hotels

\section{Introduction}

There is a worldwide concern focusing on good practices against environmental degradation and analyzing the reasons that threat sustainable development. Undoubtedly, business activities play an essential role to environmental degradation. That's why environmental management has become an important component in business's strategic agenda. Within this context, in Greece tourism sector is blooming accounting $18.5 \%$ of the nation's GDP. However, tourism businesses operators disregard environmental pressure caused because of unsustainable use of natural resources [1]. The United Nations World Tourism Organization called for drastic reduction in greenhouse gas emissions from tourism of around 25-30\% by 2020 and $50 \%$ by 2035 (with 2005 being taken as the base year) [2]. Within this context, the implementation of EMS schemes is an expression of sustainable entrepreneurship through the improvement of firm's environmental performance. Research on the adoption of environmental management system schemes in the hospitality sector, such as ISO 14001, has increased [3-10]. Researchers proved that the shift in environmental policy towards adoption of environmental management systems schemes had not only environmental but also economic and managerial benefits on the part of hotels due to improvement of firms' corporate environmental image [3-7].However, the adoption of EMS in the hospitality sector was proved difficult due to both organizational and human related factors [7-9]. Managers' perception of firms' environmental performance is linked to hotels' environmental strategy. Thus, analyzing hotel managers' viewpoint on the pros and cons of eco-labels can proved useful information on involvement in environmental management of other green hotel [10-12]. Taking all the above-mentioned into consideration, the purpose of this study is to provide evidence about the profile of ISO 14001 and Green Key certified hotels based on managers' perspective employing cross sectional data from in Athens, Greece.

\section{Methodology of the research}

\subsection{Description of the Sample}

The studied target group comprised the total number of hotels in Athens, according to the records of the Hellenic Chamber of Hotels. Given the purpose of our study we first contact general manager of each hotel to 
ensure that hotels included in our sample had an ISO 14001 or a Green Key certification. The total number of certified hotels was 82 out of 445 . Thus, structured questionnaires were e-mailed to the general manager of each hotel. A general manager is most likely the one involved in planning and implementing of EMS in a hotel. Ultimately, 70 responses were obtained, a response rate of $85.4 \%$. The questionnaire included mostly closed type questions regarding operational and economic characteristics of the hotels and factors affecting the environmental management of their business.

\subsection{Econometric Model}

Previous studies stressed the importance of compliance with environmental standards for improving the corporate environmental image of businesses. Thus, we attempt to identify factors that differentiate managers' perspective towards the beneficiary impacts of implementing EMSs, such as ISO 14001 and Green key, towards improvement of hotels' corporate profile. For this reason, the following model is specified:

$$
\operatorname{Logit}[\operatorname{Pr}(Y=1)]=\beta_{o}+\beta_{1} \text { Rooms }_{i t}+\beta_{2} \text { Class }_{i t}+\beta_{3} \text { Age }_{i t}+\beta_{5} \operatorname{Profts}_{i t}+\beta_{6} \text { Energy }_{i t}+\varepsilon_{i t}
$$

In the above equation $\mathrm{Y}$ is a binary variable indicating whether the manger reported that getting an ISO 14001 or a Green Key certificate gave a marketing advantage to his hotel through improving its environmental corporate image or not; specifically, the variable takes the value 1 when the manager answered positively and zero otherwise. Rooms is a quantitative variable representing hotel's size, Class is a quantitative variable accounting for hotel class, ranging from one to five star hotels. Age is a qualitative variable expressing the years since the hotels' establishment. Profit is quantitative variable indicating the average annual profits of the business in $€$, Energy is quantitative variable indicating the average annual energy cost of the business in $€$ and $\varepsilon$ is the disturbance term. Table 2 presents the empirical results from the estimation of Eq. (1).

\section{Results}

\subsection{Profile of the Respondents}

Of the respondents, 57.1\% were ISO 14001 certified while the rest had a Green Key certification. Most respondents $(88.6 \%)$ indicated that they were responsible for all the environmental actions taken in their hotels in order to get a certification. As regards the hotel size, $38.6 \%$ of the hotels had more than 200 rooms, $42.8 \%$ had rooms ranging in number from 50 to 200 and the rest $18.6 \%$ had rooms below 50. The average number of rooms was 223. In terms of hotel class, $35.7 \%$ were three star hotels and $57.2 \%$ were four and five star hotels. As regard the number of employees in the hotels, $37.1 \%$ of the hoteliers reported that they occupied less than ten persons in their businesses, 42.9\% reported between 11 and 40 employees and the rest $20 \%$ over 40 persons. $44.3 \%$ of the managers run hotels that have been built the last two decades and the rest older premises. In terms of hotel annual profits, the majority $(78.6 \%)$ of respondents' declared profits higher than $€ 36,000$. The average monthly expenses for water and electricity resources were $€ 14,553$ and $€ 73,599$, respectively.

\subsection{Managers' Perspective on ISO 14001 and Green Key}

Of the respondents, 30\% agreed that being certified with an ISO 14001 or a Green Key is an important competitive advantage for their hotels, $60 \%$ were neutral while only $10 \%$ disagreed. Table 1 presents managers' perspective regarding barriers that their hotels faced in order to meet the certification criteria. As shown in Table 1, budgetary barriers, including difficulties to fund and finance environmental strategies (62.9\%) and high implementation cost of environmental practices (74.3\%), are considered to be the most important barriers to obtain formal EMSs in the hotel sector. Managers claimed that they do not consider environmental actions taken by their businesses as investments with increased uncertainty of returns (77.1\%). Contrary, informational limitations are also considered to significantly hinder factors for obtaining EMSs. $47.1 \%$ reported a lack of accurate information regarding environmental management investments that were necessary in order to get an ISO 14001 or a Green Key certification. In the meantime, $28.6 \%$ of the sampled managers pointed out the negative influence of insufficient expertise among their personnel on the adoption of a formal EMS. Finally, the 
majority of the managers mentioned bureaucracy (70\%) and rigidity of environmental legislation (62\%) as barriers to meeting the certification criteria of an ISO 14001 or a Green Key in their hotels.

TABLE 1: BARRIERS OF GETTING AN ISO 14001 OR A GREEN KEY CERTIFICATION

\begin{tabular}{llll}
\hline \hline Barriers & Mean & Yes $(\%)$ & No $(\%)$ \\
\hline Lack of funding environmental management practices & 0.629 & 62.9 & 37.1 \\
High implementation cost of environmental actions & 0.743 & 74.3 & 25.7 \\
Increased uncertainty of returns of the necessary investments & 0.229 & 22.9 & 77.1 \\
Lack of know-how on implementing environmental actions & 0.229 & 22.9 & 77.1 \\
Lack of time & 0.257 & 25.7 & 74.3 \\
Lack of accurate information & 0.471 & 47.1 & 52.9 \\
Lack of expertise personnel & 0.286 & 28.6 & 71.4 \\
Administration has other priorities & 0.357 & 35.7 & 64.3 \\
Rigidity of environmental legislation & 0.614 & 61.4 & 38.6 \\
Bureaucratic problems & 0.686 & 68.6 & 31.4 \\
\hline \hline
\end{tabular}

Fig. 1 shows managers' perspective regarding the benefits gained for their business by complying with ISO 14001 and Green Key criteria. The most important benefit is characterized the marketing advantage that hotel gained through improving its corporate environmental image $(78.6 \%)$. $70 \%$ of the managers claimed that obtaining an eco-friendly certificate, such as ISO 14001 or Green Key, resulted in cost reductions because of rational material and resource management. Finally one out of two hotel managers recognized that compliance with the certification criteria of ISO 14001 or Green Key in their hotels, has led to improved environmental performance of their businesses.

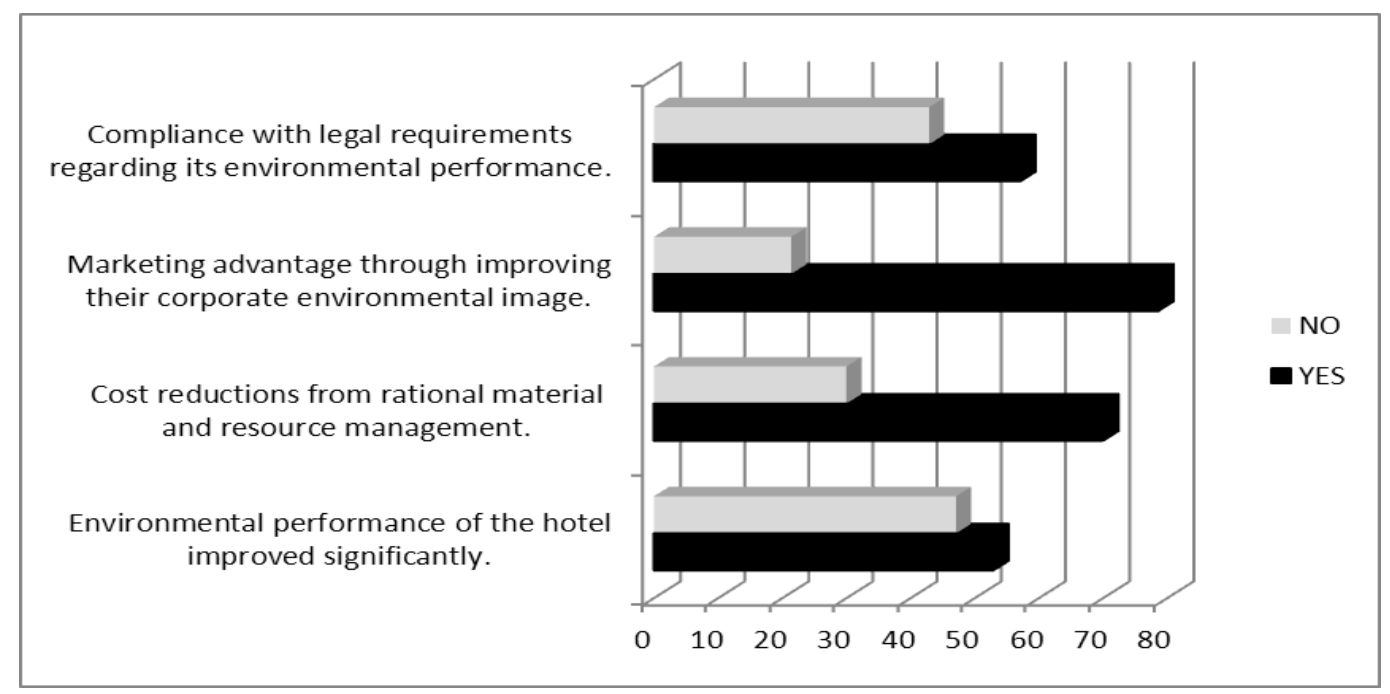

Fig. 1: Perceived benefits of being ISO 14001 or Green Key certified.

Given the perceived marketing advantage through improving hotels corporate environmental image, we next proceeded to the empirical estimation of equation (1). Table 2 presents the results obtained from the empirical estimation of Eq. (1). As follows from Table 2, the hotel's size has a statistical significant effect with a negative sing. Thus, it is estimated that managers that believe that gaining an environmental certificate gives a competitive advantage to the firms are less probable to run big hotels. Contrary, the importance of marketing advantage through improving corporate environmental image of the hotels is increasing as the class of the hotel increases too. Results suggest that managers who believe that being ISO 14001 or Green Key certified gave competitive advantage to their hotels' profile are $40 \%$ less probable to have increased annual profits, at a $1 \%$ level of significance. These results explains why smaller firms with lower profits implement environmental practices and publicize the environmental friendly image to gain stakeholders' legitimacy due to certification. Finally, the managers of hotels with increased energy cost are more probable than others by $3.1 \%$ to believe that their certified hotel gains marketing advantage through improving their corporate environmental image. 
TABLE 2: Estimated Binary Logistic Regression of the Perceived Marketing Advantage of Certified Hotels Through Improving Hotels' Corporate Environmental Image (yes: 1 no: 0)

\begin{tabular}{|c|c|c|c|c|}
\hline Independent variables & Acronym & Estimated Coefficients & Odds Ratio & $e \beta^{\wedge} i-1$ \\
\hline Constant & & $\begin{array}{l}1.71 \\
(1.6)\end{array}$ & - & - \\
\hline Number of rooms & Rooms & $\begin{array}{l}-0,002 * * \\
(2.28)\end{array}$ & 0.699 & 0.301 \\
\hline Hotel's class & Class & $\begin{array}{l}1.44 * * * \\
(2.88)\end{array}$ & 3.017 & 2.017 \\
\hline Age of premises & Age & $\begin{array}{l}-0.006 \\
(1.07)\end{array}$ & 0.007 & 0.993 \\
\hline Annual profits & Profits & $\begin{array}{l}-0.51 * * * \\
(4.43)\end{array}$ & 0.598 & 0.402 \\
\hline Annual energy cost & Energy & $\begin{array}{l}0.00003^{* *} \\
(2.06)\end{array}$ & 1.031 & 0.031 \\
\hline Log likelihood & & -172.927 & & \\
\hline Nagelkerke R2 & & 0.378 & & \\
\hline LR chi2(7) & & 51.74 & & \\
\hline Prob > chi2 & & 0.0001 & & \\
\hline Hosmer and Lemeshow & & $\begin{array}{l}5.52 \\
(0.532)\end{array}$ & & \\
\hline
\end{tabular}

Note: ***, ** represent levels of significance at $1 \%$ and $5 \%$, respectively. $Z$ statistics are presented in parentheses.

The Nagelkerke R square which is a measure of predictability of the proposed model is equal to 0.378 . The $\log$ likelihood statistic is quite high, rejecting the null hypothesis and concluding that at least one of the estimated coefficients is different from zero. The overall significance of the model is given by $\chi 2=51.74$ with a significance level of $p=0.0001$. Based on this value we can reject $\mathrm{H} 0$ (where $\mathrm{H} 0$ : $\beta 0=\beta 1=\beta 2=\beta 3=\beta 4$ $\beta 5=\beta 6=\beta 7=\beta 8=\beta 9=\beta 10=0$ ) and conclude that at least one of the $\beta$ coefficients is different from zero. The Hosmer and Lemeshow value is equal to 5.52 with significance value equal to 0.532 . The non-significant $\chi^{2}$ value indicates a good model fit in the correspondence of the actual and predicted values of the dependent variable.

\section{Conclusions}

This study provides evidence about the profile of ISO 14001 and Green Key certified hotels based on managers' perspective employing cross sectional data from in Athens, Greece. Results, acquired from hoteliers, support that they faced financial and bureaucratic problems when adopting actions to get a formal EMS scheme rather than human related or organisational. Contrary, managers stressed as important benefits of being environmentally certified the reduction costs due to rational use of resources and the promotion of corporate environmental profile. These results have significant implications while suggesting that adoption of environmental management standards provides hoteliers the relevant incentives to improve their environmental performance. Given that the touristic sector flourishes in Greece, the exploitation and diffusion of certified ecofriendly business practices in that sector is considered to be important in achieving not only economic but also environmental benefits from promotion of sustainable development practises in the tourism sector.

\section{References}

[1] C. Akrivos, P. Reklitis, and M. Theodoroyiani, "Tourism Entrepreneurship and the Adoption of Sustainable Resources. The Case of Evritania Prefecture, Procedia - Social and Behavioral Sciences, vol. 148, pp. 378-382, March 2014. https://doi.org/10.1016/j.sbspro.2014.07.056

[2] World Tourism Organization. (2009). From Davos to Copenhagen and beyond: Advancing tourism's response to climate change. UNWTO Background Paper.

[3] R. Buckley, "Tourism Ecolabels”, Annals of Tourism Research, vol. 29(1), pp. 183-208, January 2002. 
https://doi.org/10.1016/S0160-7383(01)00035-4

[4] J. Bendell, and X. Font, "Which tourism rules? Green standards and GATS", Annals of Tourism Research, vol. 31(1), pp. 139-156, January 2004.

https://doi.org/10.1016/j.annals.2003.10.001

[5] E. Chan, "Barriers to EMS in the hotel industry", International Journal of Hospitality Management, 27, pp. 187-196, March 2008.

[6] E.S.W. Chan, and S. Wong, "Motivations for ISO 14001 in the hotel industry", Tourism Management, vol. 27, pp. 481 - 492, June 2006.

https://doi.org/10.1016/j.tourman.2004.10.007

[7] E. S. W. Chan, and R. Hawkins, "Attitude towards EMSs in an international hotel: An exploratory case study", International Journal of Hospitality Management, vol. 29(4), pp. 641 - 651, December 2010.

https://doi.org/10.1016/j.ijhm.2009.12.002

[8] J. Carmody, and H. Zeppel, "Specialist accommodation operations in North Queensland: barriers to the implementation of environmental management practices", International Journal of Management and Decision Making, vol. 10, pp. 201, March 2009.

https://doi.org/10.1504/IJMDM.2009.024988

[9] J. F. Molina-Azorín, E. Claver-Cortés, J. Pereira-Moliner, and J. J. Tarí, "Environmental practices and firm performance: an empirical analysis in the Spanish hotel industry", Journal of Cleaner Production, vol. 17(5), pp. 516524, March 2009.

https://doi.org/10.1016/j.jclepro.2008.09.001

[10] Font, X. "Environmental certification in tourism and hospitality: Progress, Process and Prospects", Tourism Management, vol. 23(3), pp. 197-205, June 2002.

https://doi.org/10.1016/S0261-5177(01)00084-X

[11] Y.-C. Chen, and Y.-T. Chen, "The Advantages of Green Management for Hotel Competitiveness in Taiwan: In the Viewpoint of Senior Hotel Managers", Journal of Management and Sustainability, vol. 2(2), pp. 211-218, June 2012. https://doi.org/10.5539/jms.v2n2p211

[12] J. Park, H. Jeong Kim, and K. W. McCleary, "The Impact of Top Management's Environmental Attitudes on Hotel Companies' Environmental Management”, Journal of Hospitality \& Tourism Research, vol. 38(1), pp. 95-115, July 2012.

https://doi.org/10.1177/1096348012452666 